\title{
CD 117 Immunoexpression in Invasive Breast Carcinoma: Association with Various Prognostic Parameters.
}

\author{
Poornima Raikar*, B. Deepak Kumar, Srinivasa Murthy V \\ Department of Pathology ,Employees' State Insurance Corporation Medical College and Postgraduate Institute of \\ Medical Sciences and Research., Rajajinagar, Bangalore, Karnataka, India.
}

\begin{abstract}
Background: CD 117 (Cluster Differentiation 117), encoded by the proto-oncogene C-Kit is a transmembrane tyrosine kinase growth factor receptor which inhibits apoptosis and potentiates cell proliferation. In normal breast epithelium, c-kit is highly expressed; however, its expression is low or completely lost in primary invasive breast carcinoma, suggesting its role in breast carcinogenesis.

Objective: To evaluate the expression of CD 117 in invasive breast carcinoma and to study its association with various prognostic factors.

Materials and Methods: Fifty cases of invasive breast carcinoma of different histological types and grades were evaluated for CD117 immunoexpression and the association of the same was studied with respect to various prognostic factors, ER/PR receptor status and Her2/ neu status.

Results: A statistically significant association was seen between negative expression of CD 117 with increased age ( $\mathrm{p}=0.04)$, higher tumor grade $(\mathrm{p}=0.02)$, positive hormone receptor status (ER; $\mathrm{p}=0.001, \mathrm{PR} ; 0.005)$, negative Her $2 / \mathrm{neu}(\mathrm{p}=0.006)$ and tumors having a microvascular density of more than 19 per high power field ( $\mathrm{p}-0.01)$.

Conclusion: CD 117 immunoexpression, either negative or positive in invasive breast carcinoma has to be reported on a routine basis as a negative expression projects the prognosis of breast carcinoma patients and a positive expression will identify patients for a potential therapeutic intervention.
\end{abstract}

Keywords: Invasive Breast Carcinoma, CD 117, Prognostic Parameters.

\section{Introduction}

CD 117 (Cluster Differentiation 117), encoded by the proto-oncogene $\mathrm{C}-\mathrm{Kit}$ is a transmemberane tyrosine kinase growth factor receptor which inhibits apoptosis and potentiates cell proliferation. ${ }^{[1-3]} \mathrm{As} \mathrm{C}$-kit appears to play a central role in cellular transformation and differentiation, aberrant activation of c-kit leads to development and progression of several human malignancies. ${ }^{[4-6]}$ Increased c-kit expression has been found in various malignant tumors such as myeloid leukemias, small cell lung carcinomas and gastrointestinal stromal tumors. On the contrary, reduced expression or complete loss of expression in seen in melanomas ${ }^{[7]} \mathrm{C}$-kit alterations in malignant tumors have been of considerable interest to researchers and treating surgeons as c-kit is one of the targets of tyrosine kinase inhibitor, imatinib mesylate. ${ }^{[2]}$

In normal breast epithelium, c-kit is highly expressed, however, its expression is low or completely lost in primary invasive breast carcinoma, suggesting its role in breast carcinogenesis. ${ }^{\left[{ }^{[8,9]}\right.}$ Various studies have indicated that lack of c-kit is associated with high grade breast carcinoma. $[1,3,10]$ This study was conducted to evaluate the expression of CD 117 in invasive breast carcinoma and to study its association with various prognostic factors.

\section{Materials and Methods}

Fifty cases of invasive breast carcinoma of different histological types and grades were included in the study. Clinicopathological parameters such as age, histopathological type, histological grade, tumor size, and lymph node metastasis were studied. Histological typing of breast carcinoma cases was done according to the WHO criteria. The histological grade was assessed using modified Bloom-Richardson classification. Sections from $10 \%$ Neutral buffered formalin-fixed, paraffin-embedded tumor tissue blocks were immunostained with ER, PR, Her 2/ neu, CD 34 for microvascular density and CD 117. Allred scoring system was used for hormone receptors. [11] American Society of Clinical Oncology/College of American Pathologists guidelines were followed for Her 2/neu scoring. ${ }^{[12]}$ For evaluation of microvascular density, number of vessels per high power field were counted in immunohistochemistry slides stained for CD 34. ${ }^{[1]} \mathrm{CD} 117$ immunostaining was evaluated on a score of zero to $2+$. Cytoplasmic and membrane staining of the tumor cells 
by CD 117 was considered to be positive. CD 117 stain was scored 0 when no staining was observed or staining was observed in less than $10 \%$ of epithelial cells; score $1+$ was given when the cytoplasm was discretely and weakly moderately stained in $10 \%$ or more of the epithelial cells and score $2+$ when the cytoplasm was strongly stained with or without membrane staining in $10 \%$ or more of the epithelial cells. Cases with score 0 was considered as negative and cases with a score of $1+$ and $2+$ were considered positive. ${ }^{[1]}$ Immunoexpression of CD 117 in tumour cells was correlated with tumor size, tumor grade, lymph node metastasis, hormone receptors and microvessel density for any statistically significant association. Chi square test was used to assess the statistical significance. A $\mathrm{P}$ value $<0.05$ was considered statistically significant.

\section{Results}

Out of 50 cases taken for the study, age of patients ranged from 24 to 74 yrs with a mean age of 49 yrs. All the patients, expect one were females (98\%). Infiltrating ductal carcinoma accounted for $92 \%$ of cases. Majority of the cases $(50 \%)$ belonged to grade II. $53.6 \%$ of cases showed metastatic deposits out of 41 cases for which details of lymph node involvement was available. Estrogen receptor was positive in $46 \%$ of cases, progesterone receptor in $42 \%$ and $20 \%$ were positive for Her 2 neu status. Microvascular density of $>19$ per high power field was seen in $54 \%$ of cases. CD 117 immunoreactivity was seen in 21 (42\%) cases.

Comparison of CD 117 expression with various clinical, histological and immunohistochemical parameters showed the following results.
CD 117 expression with clinical parameters: No CD 117 immunoexpression was seen in majority of patients with age $>40$ years $(65.7 \%)$ and with tumor size of $>2 \mathrm{~cm}$ (86.2\%). This negative expression of CD 117 with respect to increasing age was statistically significant $(p=0.04)$. However no statistical significance was seen with respect to tumor size.

CD 117 expression with histological parameters: Negative expression of CD 117 was seen in majority of breast carcinoma cases $(75 \%)$ of histological type other than the conventional infiltrating ductal carcinoma - NOS and in node negative status individuals. With respect to grade of the tumor, negative CD 117 expression was seen in $83.3 \%$ of grade 3 tumors as against $52 \%$ and $28.5 \%$ of grade 2 and grade 1 tumors respectively. This association of negative CD 117 expression with a higher tumor grade was found to be statistically significant $(\mathrm{p}=0.02)$.

CD 117 expression with immunohistochemical parameters: Majority of negative CD 117 expression was seen in estrogen receptor positive status tumors $(82.6 \%)$. The same was observed with respect to Progesterone receptor positive tumors (80.9). On the contrary, Her2 receptor negativity was associated with negative CD 117 expression in $67.5 \%$ of tumors. The association of negative CD 117 immunoexpression with positive hormone receptor status (ER, PR) and negative Her2/neu status was found to be statistically significant. $(\mathrm{p}=0.001,0.005$ and 0.006 respectively). $74 \%$ of tumors having a microvascular density of more than 19 per high power field showed negative expression of CD 117. This association was found to be statistically significant. (p-0.01).

Table 1: Association of CD117 immunoexpression with various prognostic parameters.

\begin{tabular}{|c|c|c|c|c|c|}
\hline \multirow{3}{*}{$\begin{array}{l}\text { Clinicopathological } \\
\text { parameters }\end{array}$} & \multirow{3}{*}{$\begin{array}{l}\text { Number of cases } \\
\qquad(n=50)\end{array}$} & \multicolumn{3}{|c|}{ CD 117 expression } & \multirow{3}{*}{$P$ value } \\
\hline & & \multirow{2}{*}{$\begin{array}{l}\text { Negative } \\
\text { Score } 0\end{array}$} & \multicolumn{2}{|c|}{ Positive } & \\
\hline & & & Score 1+ & Score 2+ & \\
\hline \multicolumn{6}{|c|}{ Age } \\
\hline$<40$ & $\begin{array}{c}12 \\
(24 \%)\end{array}$ & $\begin{array}{c}04 \\
(33.3 \%)\end{array}$ & $\begin{array}{c}06 \\
(50 \%)\end{array}$ & $02(16.6 \%)$ & \multirow{2}{*}{0.047} \\
\hline$>40$ & $\begin{array}{c}38 \\
(76 \%)\end{array}$ & $\begin{array}{c}25 \\
(65.7 \%)\end{array}$ & $\begin{array}{c}10 \\
(26.3 \%)\end{array}$ & $\begin{array}{c}03 \\
(7.9 \%)\end{array}$ & \\
\hline \multicolumn{6}{|c|}{ Size } \\
\hline$<2$ & $\begin{array}{c}08 \\
(16 \%)\end{array}$ & $\begin{array}{c}04 \\
(50 \%)\end{array}$ & $\begin{array}{c}04 \\
(50 \%)\end{array}$ & $\begin{array}{c}00 \\
(00 \%)\end{array}$ & \multirow{3}{*}{0.645} \\
\hline $2-5$ & $\begin{array}{c}30 \\
(60 \%)\end{array}$ & $\begin{array}{c}19 \\
(63.3 \%)\end{array}$ & $\begin{array}{c}08 \\
(26.6 \%)\end{array}$ & $\begin{array}{c}03 \\
(10 \%)\end{array}$ & \\
\hline$>5$ & $\begin{array}{c}12 \\
(24 \%)\end{array}$ & $\begin{array}{c}06 \\
(50 \%)\end{array}$ & $\begin{array}{c}04 \\
(30 \%)\end{array}$ & $\begin{array}{c}02 \\
(20 \%)\end{array}$ & \\
\hline
\end{tabular}




\begin{tabular}{|c|c|c|c|c|c|}
\hline \multirow{3}{*}{$\begin{array}{l}\text { Clinicopathological } \\
\text { parameters }\end{array}$} & \multirow{3}{*}{$\begin{array}{l}\text { Number of cases } \\
\qquad(n=50)\end{array}$} & \multicolumn{3}{|c|}{ CD 117 expression } & \multirow{3}{*}{$P$ value } \\
\hline & & \multirow{2}{*}{$\begin{array}{l}\text { Negative } \\
\text { Score } 0\end{array}$} & \multicolumn{2}{|c|}{ Positive } & \\
\hline & & & Score 1+ & Score 2+ & \\
\hline \multicolumn{6}{|c|}{ Histological Type } \\
\hline IDC & $\begin{array}{c}46 \\
(92 \%)\end{array}$ & $\begin{array}{c}26 \\
(56.5 \%)\end{array}$ & $\begin{array}{c}15 \\
(32.6 \%)\end{array}$ & $\begin{array}{c}05 \\
(10.8 \%)\end{array}$ & \multirow{2}{*}{0.472} \\
\hline Others & $\begin{array}{c}04 \\
(08 \%)\end{array}$ & $\begin{array}{c}03 \\
(75 \%)\end{array}$ & $\begin{array}{c}01 \\
(25 \%)\end{array}$ & $\begin{array}{c}00 \\
(00 \%)\end{array}$ & \\
\hline \multicolumn{6}{|c|}{ Grade } \\
\hline 1 & $\begin{array}{c}07 \\
(14 \%)\end{array}$ & $\begin{array}{c}02 \\
(28.5 \%)\end{array}$ & $\begin{array}{c}05 \\
(71.4 \%)\end{array}$ & $\begin{array}{c}00 \\
(00 \%)\end{array}$ & \multirow{3}{*}{0.022} \\
\hline II & $\begin{array}{c}25 \\
(50 \%)\end{array}$ & $\begin{array}{c}13 \\
(52 \%)\end{array}$ & $\begin{array}{c}08 \\
(32 \%)\end{array}$ & $\begin{array}{c}04 \\
(16 \%)\end{array}$ & \\
\hline III & $\begin{array}{c}18 \\
(38 \%)\end{array}$ & $\begin{array}{c}15 \\
(83.3 \%)\end{array}$ & $\begin{array}{c}02 \\
(11.1 \%)\end{array}$ & $\begin{array}{c}01 \\
(5.5 \%)\end{array}$ & \\
\hline \multicolumn{6}{|c|}{ Lymph Node Involvement } \\
\hline Positive & $\begin{array}{c}22 \\
(53.6 \%)\end{array}$ & $\begin{array}{c}10 \\
(45.4 \%)\end{array}$ & $\begin{array}{c}08 \\
(36.3 \%)\end{array}$ & $\begin{array}{c}04 \\
(18.1 \%)\end{array}$ & \multirow{2}{*}{0.426} \\
\hline Negative & $\begin{array}{c}19 \\
(46.3 \%)\end{array}$ & $\begin{array}{c}11 \\
(57.8 \%)\end{array}$ & $\begin{array}{c}07 \\
(36.8 \%)\end{array}$ & $\begin{array}{c}01 \\
(5.2 \%)\end{array}$ & \\
\hline \multicolumn{6}{|c|}{ Estrogen receptor status } \\
\hline Positive & $\begin{array}{c}23 \\
(46 \%)\end{array}$ & $\begin{array}{c}19 \\
(82.6 \%)\end{array}$ & $\begin{array}{c}04 \\
(17.3 \%)\end{array}$ & $\begin{array}{c}0 \\
(00 \%)\end{array}$ & \multirow{2}{*}{0.001} \\
\hline Negative & $\begin{array}{c}27 \\
(54 \%)\end{array}$ & $\begin{array}{c}10 \\
(37 \%)\end{array}$ & $\begin{array}{c}12 \\
(44.4 \%)\end{array}$ & $\begin{array}{c}5 \\
(18.5 \%)\end{array}$ & \\
\hline \multicolumn{6}{|c|}{ Progesterone receptor status } \\
\hline Positive & $\begin{array}{c}21 \\
(42 \%)\end{array}$ & $\begin{array}{c}17 \\
(80.9 \%)\end{array}$ & $\begin{array}{c}04 \\
(19 \%)\end{array}$ & $\begin{array}{c}0 \\
(00 \%)\end{array}$ & \multirow{2}{*}{0.005} \\
\hline Negative & $\begin{array}{c}29 \\
(58 \%)\end{array}$ & $\begin{array}{c}12 \\
(41.3 \%)\end{array}$ & $\begin{array}{c}12 \\
(41.3 \%)\end{array}$ & $\begin{array}{c}5 \\
(17.2 \%)\end{array}$ & \\
\hline \multicolumn{6}{|c|}{ Her2/neu status } \\
\hline Positive & $\begin{array}{c}10 \\
(20 \%)\end{array}$ & $\begin{array}{c}02 \\
(20 \%)\end{array}$ & $\begin{array}{c}07 \\
(70 \%)\end{array}$ & $\begin{array}{c}01 \\
(10 \%)\end{array}$ & \multirow{2}{*}{0.006} \\
\hline Negative & $\begin{array}{c}40 \\
(80 \%)\end{array}$ & $\begin{array}{c}27 \\
(67.50 \%)\end{array}$ & $\begin{array}{c}09 \\
(22.5 \%)\end{array}$ & $\begin{array}{c}04 \\
(10 \%)\end{array}$ & \\
\hline \multicolumn{6}{|c|}{ MVD } \\
\hline$>19$ & $\begin{array}{c}27 \\
(54 \%)\end{array}$ & $\begin{array}{c}20 \\
(74 \%)\end{array}$ & $\begin{array}{c}05 \\
(18.5 \%)\end{array}$ & $\begin{array}{c}2 \\
(7.4 \%)\end{array}$ & \multirow{2}{*}{0.012} \\
\hline$<19$ & $\begin{array}{c}23 \\
(46 \%)\end{array}$ & $\begin{array}{c}09 \\
(39.1 \%)\end{array}$ & $\begin{array}{c}11 \\
(47.8 \%)\end{array}$ & $\begin{array}{c}3 \\
(13 \%)\end{array}$ & \\
\hline
\end{tabular}




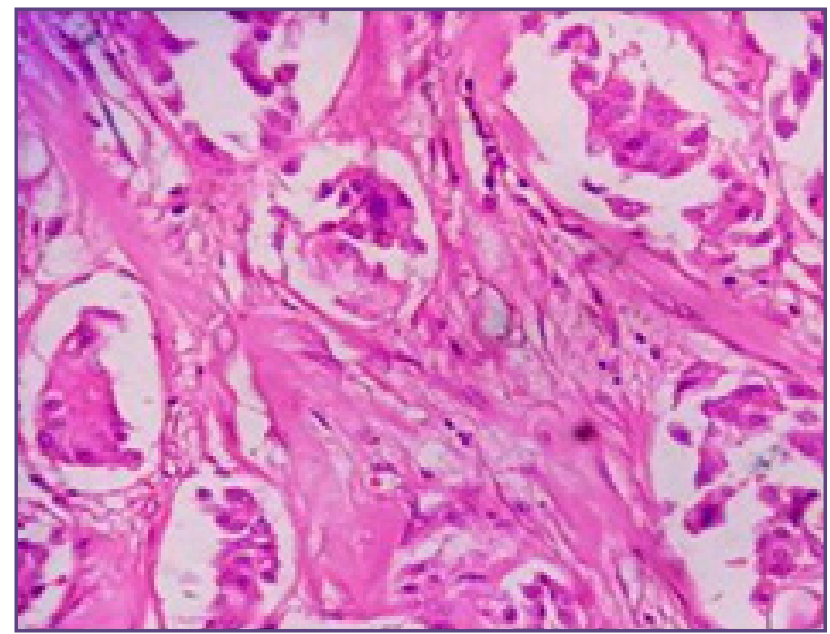

Fig. 1: Infiltrating ductal carcinoma grade I(x40).

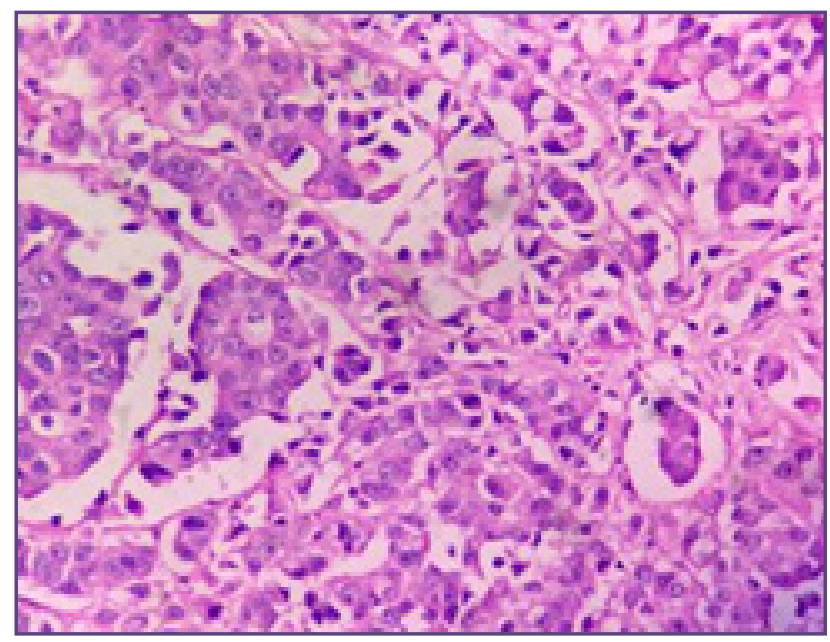

Fig. 3: Infiltrating ductal carcinoma grade III(x40).

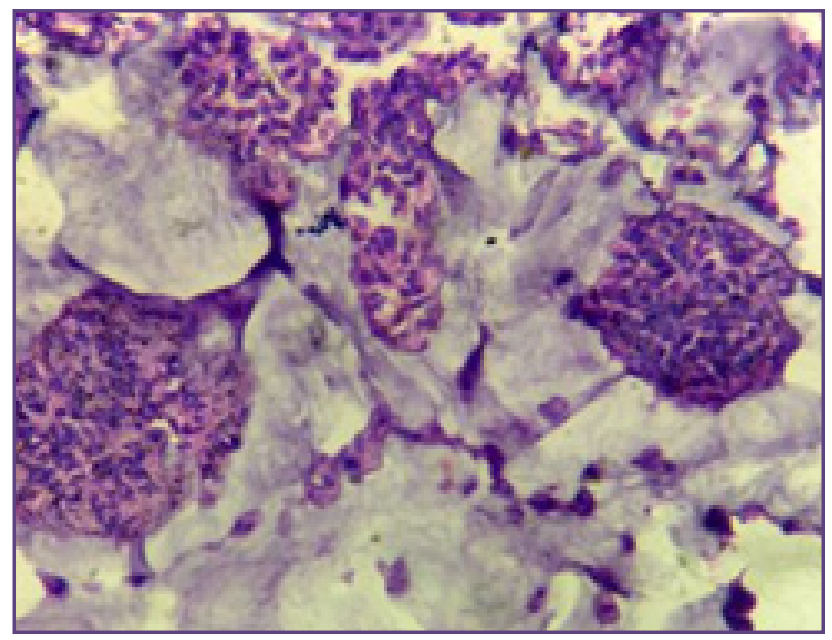

Fig. 5: Mucinous carcinoma of Breast, $(\mathrm{x40})$.

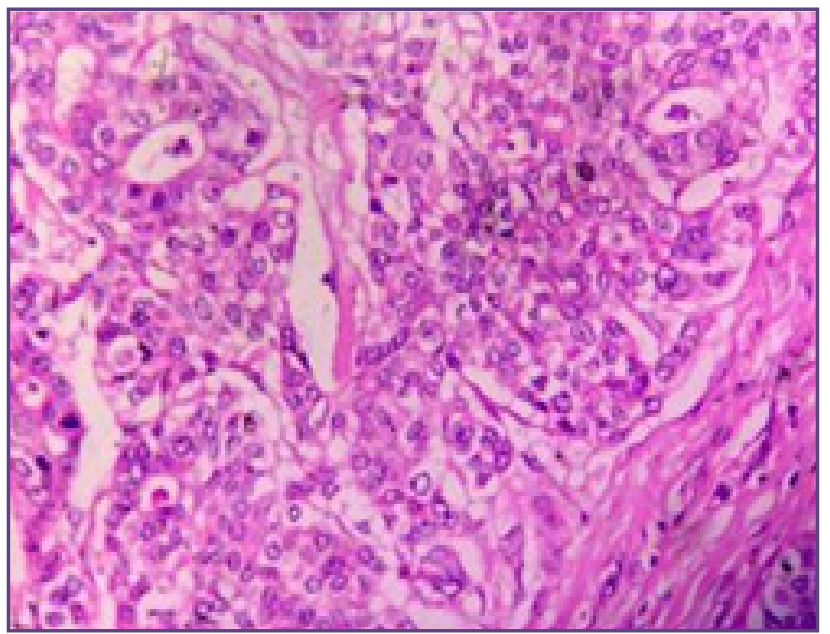

Fig. 2: Infiltrating ductal carcinoma grade II(x40).

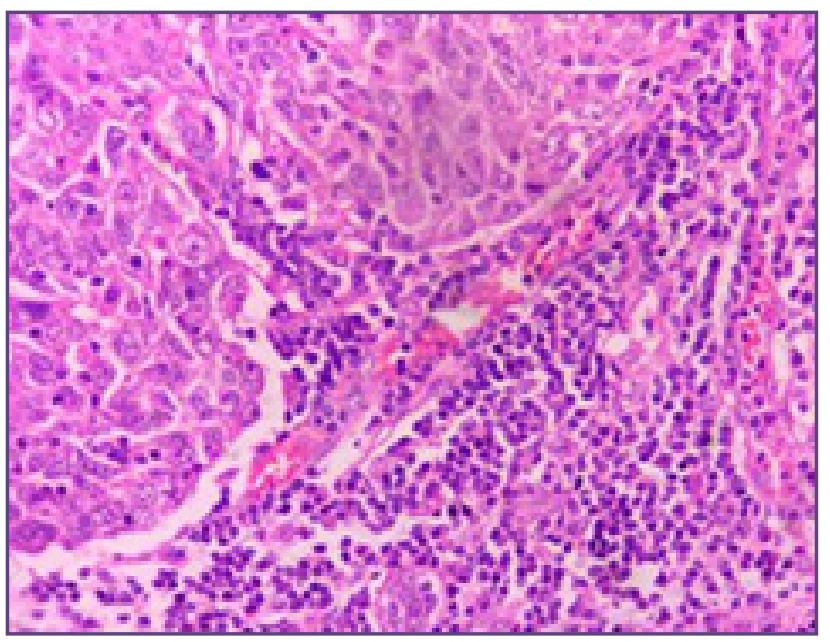

Fig. 4: Medullary carcinoma of Breast(x40).

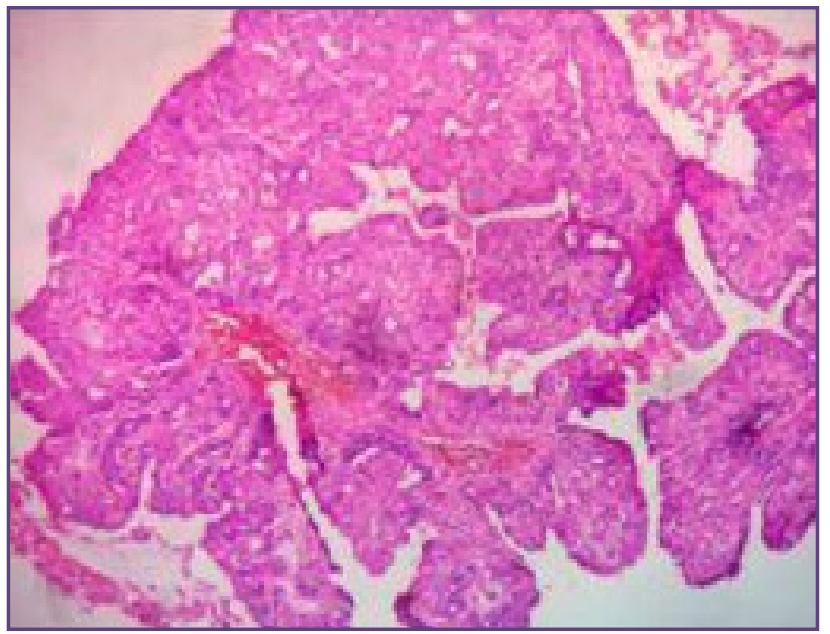

Fig. 6: Intracystic papillary carcinoma of Breast, (x10). 


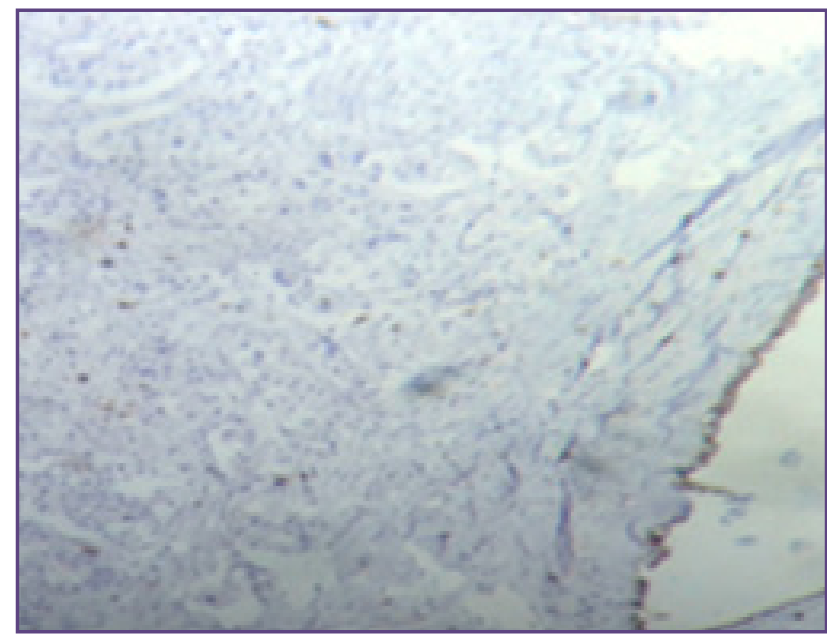

Fig. 7: CD 117 Negative expression score $0(x 10)$.

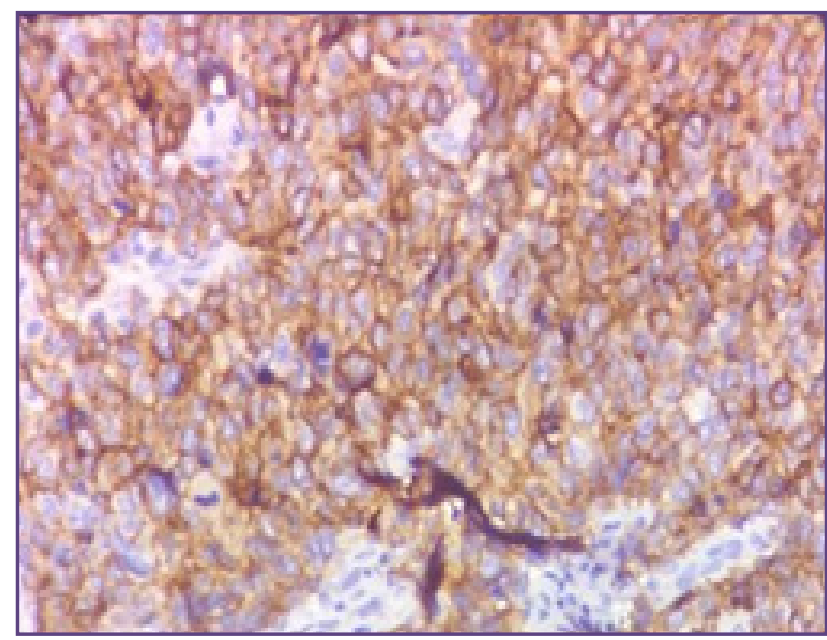

Fig. 9: CD 117 Positive expression score $2+(x 40)$

\section{Discussion}

Among the various signal transduction pathways within the human cells, at least four such main signal transduction pathways are identified which are activated by interaction of an extracellular ligand with its corresponding receptors. Signal transduction pathways express protein that regulates the cell cycle, but they do not directly participate in controlling cell cycle events. ${ }^{[13]}$ One of them is activation of tyrosine kinase. C-kit protein, also known as stem cell factor receptor (SCFR) or CD 117 is a kinase necessary for cell division, showing decreased or increased expression in some malignancies. ${ }^{[14]} \mathrm{C}$-kit protein expression has been found in malignancies such as myeloid leukemia, small cell lung cancer, seminomas and gastrointestinal stromal tumors. ${ }^{[10]}$ Reduced expression or loss of c-kit expression is seen in high grade breast carcinoma, ${ }^{[1,3,4]}$ advanced ovarian cancers, ${ }^{[15]}$ and melanomas. ${ }^{[7]}$ In breast, kit protein is expressed in normal breast epithelium, non-neoplastic

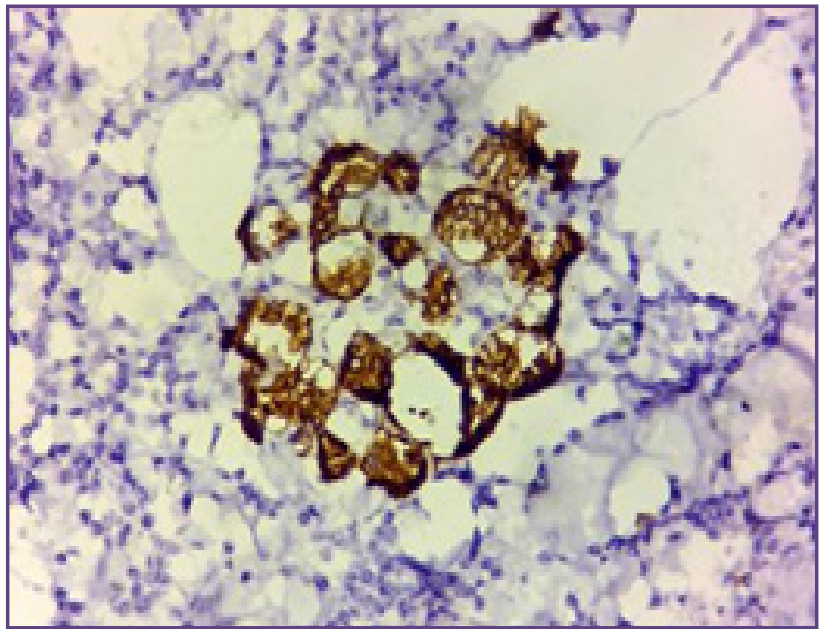

Fig. 8: CD 117 Positive expression score 1+(x40).

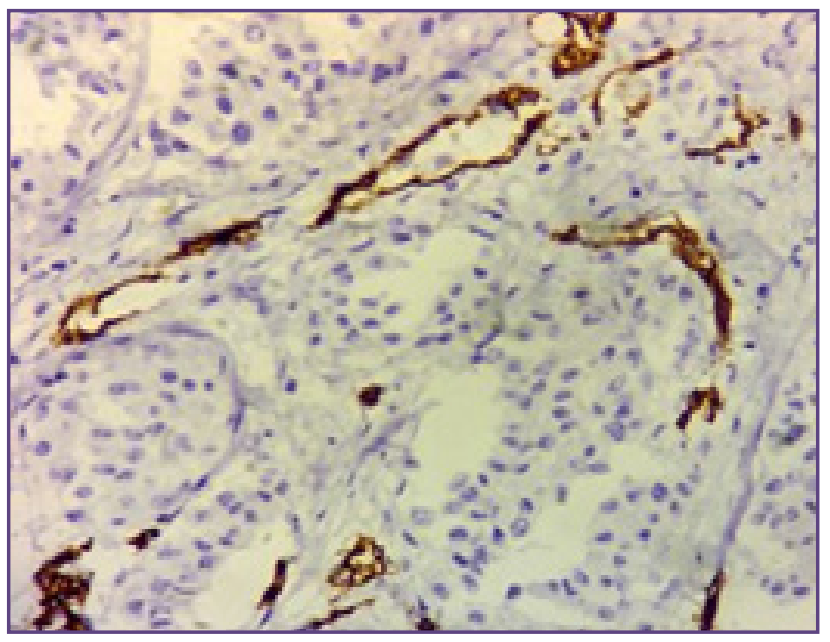

Fig. 10: Blood vessels showing CD 34 staining(x40).

diseases and in $1-13 \%$ of cancers. ${ }^{[16,17,18]}$ Several studies have indicated the expression of CD 117 in malignant breast tumors to be in the range of 14.7 to $58.3 \%$. $^{[1,7,17,19,20]}$ The present study showed CD 117 expression in invasive breast carcinoma to be $42 \%$.

Several studies by various authors have been conducted in the past to determine the association of CD 117 expression with relation to various prognostic factors in breast carcinoma such as age, tumor size, tumor grade, lymph node involvement by the tumor, hormone receptor status, Her2 /neu status and microvascular density.

Association of CD 117 with respect to age, tumor size, tumor grade and lymphnode involvement: In a study by Amim et al ${ }^{[1]}$, wherein $28.6 \%$ of invasive breast carcinoma were positive for CD 117 expression, significant differences were observed between the expression of CD 117 in tumor epithelial cells with respect to patient age, tumor size, 
tumor grade and lymph nose involvement by the tumor. Studies conducted by Chui et al ${ }^{[10]}$ and Susruthan $M$ et al ${ }^{[19]}$ showed no statistically significant difference of CD 117 expression with tumor size and lymph node status. El-sayed $\mathrm{M}$ et al ${ }^{[7]}$ in his study conducted on 30 breast carcinoma cases showed significant association of CD 117 expression with lymph node involvement. The present study showed association of CD 117 expression with respect to age and grade of the tumor.

Association of CD 117 with respect to hormone receptor status, Her2/neu status and microvascular density: Amim et al ${ }^{[1]}$ documented statistically significant association of CD 117 expression with ER expression, PR expression and microvascular density, however no association was seen with Her2/neu expression. On the contrary Chui et al ${ }^{[17]}$ and El-Sayed $\mathrm{M}$ et al ${ }^{[7]}$ found a significant association of CD 117 expression with only Her2/neu receptor status. Susruthan M et al ${ }^{[19]}$ in his study on 62 cases of invasive breast carcinoma did not find any association of CD 117 expression with hormone receptors or Her2/neu expression. The present study showed an association of CD 117 expression with ER status, PR status, Her2/neu status and microvascular density.

In the present study, loss of CD 117 expression was seen in patients more than 40 years of age, high-grade tumors, negative Her2/neu status and high microvascular density. CD 117 can be used as a prognostic marker, given its nature of expression in breast carcinoma and its association with other prognostic parameters. On a brighter note, breast tumors which express CD117 are also of interest because c-kit alterations in malignant tumors is one of the targets of tyrosine kinase inhibitor imatinib mesylate. As ST1571 has shown to be effective in the treatment of chronic myeloid leukemia, ${ }^{[21]}$ kit positive gastrointestinal stromal tumors $^{[22]}$ and dermatofibrosarcoma protruberans, ${ }^{[23]}$ its role in the treatment of kit positive breast carcinomas can be promising.

\section{Conclusion}

CD 117 immunoexpression, either negative or positive in invasive breast carcinoma has to be reported on a routine basis as a negative expression projects the prognosis of breast carcinoma patients and a positive expression will identify patients for a potential therapeutic intervention.

\section{Disclaimer}

This article was presented by Dr. Poornima Raikar, at the $43^{\text {rd }}$ Annual State level KCIAPM Conference held at SDM Medical College, Dharward from 26.08.2016 to 28.08.2016

\section{References}

1. Amim MM, El-Hawary AK, Farouk O. Relation of CD 117 immunoreactivity and microvascular dendity in invasive breast carcinoma. Indian J Pathol Microbiol 2012;55(4):456460.

2. Simon R, Panussis S, Maurer R, Spichtin H, Glatz k, Tapia C, et al. KIT (CD117)-Positive Breast Cancers Are Infrequent and lack KIT Gene Mutations. Clin Can Res. 2004;10(1):178-183.

3. Zhao F, Chen Y, Wu Q, Wang Z, Lu J. Prognostic value of CD 117 in cancer: a meta-analysis. Int J Clin Exp Pathol 2014;7(3):1012-1021.

4. Shams TM, Shams ME. Overexpression of c-kit (CD117) in triple negative breast cancer. Egyptian Journal of Pathology 2011;31:113-117.

5. Went PT, Dirnhofer S, Bundi M, Mirlacher M, Schraml P, Mangialaio S, et al. Prevalence of KIT expression in human tunors. J Clin Oncol 2004;22:4514-4522.

6. Sihto H, Sarlomo, Rikala $M$, Tynninen $O$, Tanner $M$, Andersson LC, Franssila K, et al. KIT and Platelet-derived growth factor receptor alpha tyrosine kinase gene mutations and KIT amplifications in human solid tumors. J Clin Oncol 2005;23:49-57.

7. El-Sayed M and Shafeek MG. Expression of CD 117 in normal and neoplastic breast tissue:the diagnostic significance and correlation with Her-2, estrogen and progesterone receptors in breast cancer. Egyptian Journal of Pathology 2013;33:208-213.

8. Ko CD, Kim JS, Ko BG, Son BH, Kang HJ, Yoon HS, et al. The meaning of the c-kit protooncogene product in malignant transformation in human mammary epithelium. Clin Exp Metastasis 2003;20:593-7.

9. Tsuura Y, Suzuki T, Honma K, Sano M. Expression of c-KIT protein in proliferative lesions of human breast. Sexual difference and close association with phosphotyrosine status. J Cancer Res Clin Oncol 2002;128:239-46.

10. Kondi-Pafiti A, Arkadopoulos N, Gennatas C, Michalaki V, Frangou-Plegmenou M, Chatzipantelis P. Expression of c-kit in common benign and malignant breast lesions. Tumori 2010;96:978-984.

11. Allred DC. ASCO/CAP guidelines recommendation for IHC testing of ER and PR in breast carcinoma. J of clinical oncology. 2010: 28; 2784-2795.

12. Wolff AC, Hammond ME, Hicks DG, Dowsett M, McShane $\mathrm{LM}$, Allison $\mathrm{KH}$, et al. Recommendations for human epidermal growth factor receptor 2 testing in breast cancer: American Society of Clinical Oncology/College of American Pathologists clinical practice guideline update. Journal of Clin Oncol. 2013;31(31):3997-4013.

13. Talaiezadeh A, Jazayeri SN, Nateghi J. Expression of c-kit protein in cancer vs. normal breast tissue. Wspolczesna Onkol 2012;16(4):306-309. 
14. Linnekin D. Early signaling pathways activated by c-kit in hematopoietic cells. Int J Biochem Cell Biol 1999;31:105374.

15. Tonary AM, Macdonald EZ, Faught W, Senterman MK, Vanderhyden BC. Lack of expression of c-kit in ovarian cancers is assoxiated with poor prognosis. Int $\mathrm{J}$ Cancer 2000;89(3):242-50.

16. Tsuura Y, Suzuki T, Honma K and Sano M. Expression of c-kit protein in proliferative lesions of human breast: sexual difference and close association with phosphotyrosine status. J. Cancer Res. Clin. Oncol., 2002;128: 239-246.

17. Chui X, Egami H, Yamashita J, Kurizaki T, Ohmachi H, Yamamoto $\mathrm{S}$, et al. Immunohistochemical expression of the c-kit proto-oncogene product in human malignant and non-malignant breast tissues. British Journal of Cancer 1996;73:1233-1236.

18. Natali PG, Nicotra MR, Sures I, Mottolese M, Botti C, and Ullrich A. Breast cancer is associated with loss of the c-kit oncogene product. Int. J. Cancer 1992;52: 713-717.

19. Susruthan M, Rajendiran S, Jayanth V, Archana K, Pai V. C-kit expression in breast carcinoma - A study of 62 cases of breast carcinoma. International Journal of Recent Trends in Science and Technology 2015;15(3):597-602.

20. Pillai SKK, Tay A, Nair S, Leong C. Triple Negative breast cancer is associated with EGFR, CK 5/6 and C-KIT expression in Malaysian Women. BMC Clinical Pathology 2012;12:1-18.

21. Kantarjian H, Sawyers C, Hochhaus A, Guilhot F, Schiffer C, Gambacorti-Passerini C, et al. Hematologic and cytogenetic responses to imatinib mesylate in chronic myelogenous leukemia. N Engl J Med. 2002;346: 645-652.

22. Miettinen M, Furlong M, Sarlomo-Rikala M, Burke A, Sobin LH, and Lasota J. Gastrointestinal stromal tumors, intramural leiomyomas, and leiomyosarcomas in the rectum and anus: a clinicopathologic, immunohistochemical, and molecular genetic study of 144 cases. Am J Surg. Pathol. 2001;25:1121-1133.

23. Sawyers CL. Imatinib GIST keeps finding new indications: successful treatment of dermatofibrosarcoma protuberans by targeted inhibition of the platelet-derived growth factor receptor. J Clin Oncol. 2002;20:3568-3569.

*Corresponding author:

Dr. Poornima Raikar. MBBS, Junior Resident, Department of Pathology, Employees' State Insurance Corporation Medical College and Postgraduate Institute of Medical Sciences and Research, Rajajinagar, Bangalore, Karnataka, India. 560010.

Phone: +91 8904746841, 7892063672

Email: poornimaraikar06@gmail.com

Financial or other Competing Interests: None. 